\begin{tabular}{|c|c|c|c|}
\hline & International Journal of Current Research in \\
Biosciences and Plant Biology & Volume 5 • Number 8 (August-2018) • ISSN: 2349-8080 (Online) \\
\hline EXCELLENT \\
PUBLISHERS
\end{tabular}

\title{
Influence of the Origin of Water Pollution on the Floristic Diversity of Macrophytes of the Mfoundi Lowlands in the City of Yaounde
}

\section{Metagne Carole Tchinda ${ }^{*}$, Louis Zapfack ${ }^{1}$, Djomo Cédric Chimi ${ }^{1,2}$, Damien Marie Essono ${ }^{3}$ and Godswill Ntsomboh-Ntsefong ${ }^{4,5}$}

${ }^{1}$ Departement of Plant Biology, Laboratory of Botany \& Ecology: Research Unit: Ecology/Systematics and Assessment of Carbon stocks, Faculty of Science, PO. BOX: 812, University of Yaounde I, Cameroon

2Institute of Agricultural Research for Development, PO. BOX: 2123 Yaounde, Cameroon

3Departement of Plant Biology, Laboratory of Microbiology of Soils, Faculty of Science, PO. BOX: 812,

University of Yaounde I, Cameroon

${ }^{4}$ Departement of Plant Biology, Laboratory of Biotechnology \& Environment, Faculty of Science, PO. BOX:

812, University of Yaounde I, Cameroon

5Institute of Agricultural Research for Development, CEREPAH Dibamba, PO. BOX: 243 Douala, Cameroon

${ }^{*}$ Corresponding author.

\begin{tabular}{|c|c|}
\hline Article Info & ABSTRACT \\
\hline & \multirow{4}{*}{$\begin{array}{l}\text { The Mfoundi watershed serves as a collector of untreated sewage in the Yaounde } \\
\text { urban area. This study on the floristic diversity of this ecosystem was conducted with } \\
\text { the objective of determining the influence of water pollution on the distribution of the } \\
\text { subservient macrophytes. The inventory based on floristic records from Braun- } \\
\text { Blanquet abundance-dominance coefficients was carried out in } 90 \text { plots of } 5 \mathrm{~m} \text { x } 5 \mathrm{~m} \\
\text { distributed over } 9 \text { stations belonging to } 3 \text { tributaries (Aké, Biyeme, Ewoué) chosen on } \\
\text { the basis of the effluents they receive. The R version } 3.3 .3 \text { software was used to analyze } \\
\text { the data. The Shannon diversity index, which ranges from } 2.64 \text { to } 3.32 \text {, is indicative of a } \\
\text { richness of floristic diversity in the Mfoundi lowlands. However, they are dominated } \\
\text { by Pennisetum purpureum Schumach. ( } 14.9 \%) \text {, Commelina benghalensis L. ( } 9.3 \% \text { ) and } \\
\text { Echinochloa pyramidalis (Lam.) Hitchc. \& Chase ( } 8.4 \% \text { ). On each tributary studied, } \\
\text { Ipomoea aquatica Forsk. abundantly appears at the intermediate level and disappears } \\
\text { downstream. Other abundant species (Hydrolea glabra Schumach \& Thonn, Leersia } \\
\text { hexandra Sw. and Pistia stratiotes L.) have a fortuitous and evanescent appearance, } \\
\text { approaching the above-mentioned specie but subservient only to the Aké tributary. } \\
\text { These abundant species can give an indication of the quality of the water and guide the } \\
\text { ecological restoration of degraded environments. }\end{array}$} \\
\hline & \\
\hline Keywords & \\
\hline $\begin{array}{l}\text { Distribution } \\
\text { Macrophytes } \\
\text { Mfoundi } \\
\text { Pollution } \\
\text { Tributaries }\end{array}$ & \\
\hline
\end{tabular}

M. C. Tchinda et al. (2018) / Influence of the Origin of Water Pollution on the Floristic Diversity of Macrophytes of the 


\section{Introduction}

Human activities are one of the major causes of degradation of aquatic ecosystems (Vasquez and Favila, 1998, Priso et al., 2010, 2012 and 2014). In Cameroon, as in most developing countries, the streams in the urban areas are subjected to the discharge of untreated pollutants such as domestic sewage and industrial effluents, which degrade water quality while modifying the biodiversity of the ecosystems that constitute them (Winter and Duthie, 1998; Beyene et al., 2009). In the case of Yaounde city, industrial and agro-industrial activities develop on the Mfoundi watershed (Feudjeu, 2012). This leads to the accumulation of organic matter and increase in the basicity of water and suspended matter, which make Mfoundi a polluted watershed (Leutche et al., 2009). Despite all the work done on Mfoundi, it appears that the Mfoundi watershed is highly polluted (Ajeagah et al., 2006); this pollution of chemical and organic origin is the result of urban and industrial waste disposal in the city of Yaounde (Foto et al., 2011).

Previous studies on the quality of surface water in the city of Yaounde and more specifically the Mfoundi watershed have highlighted the presence of faecal contaminants (Foto, 1989; Kemka, 2000; Zébazé, 2000; Niyitegeka, 2001; Djuikom et al., 2009; Kuitcha et al., 2010; Nougang et al., 2011; Ajeagah et al., 2012; Anonyme, 2013). Based on physicochemical and bacteriological findings, Djuikom et al. (2009) concluded that the pollution of the Mfoundi watershed poses an increased risk of infection for the populations and that an urgent need to control the discharge of wastewater in this basin is required. Kuitcha et al. (2010) reported that the level of pollution in the Mfoundi watershed causes significant degradation of its waters and underlined the need to develop appropriate sanitation strategies. Ebang et al. (2012) have shown that epilithic diatoms are sensitive to variation in water quality of Mfoundi and can be used as bioindicators of the health status of Cameroon's urban water bodies. In this context, it is difficult with the current state of knowledge to define the specific characteristics of macrophytes in the Mfoundi watershed. However, some plants such as Echinochloa pyramidalis have the capacity to purify wastewater discharged there (Fonkou et al., 2010; Djumyom et al., 2016). In addition, plants participate in the biotic and abiotic processes that occur in ecosystems and are therefore markers of environmental change (Ramade et al., 1984, Sauberer et al., 2003).

The urban environmental health can be determined by analysis of pollutants, by satellite methods or analysis of plant communities (Priso et al., 2000; Markert et al., 2003). The study of aquatic organisms provides an analysis that integrates the contamination of ecosystems because their presence or abundance reflects the successive environmental conditions that have occurred during their development (Jüttner et al., 1996; Soininen 2002; Beyene et al., 2009). The objective of this study is to show the influence of urban pollutant released from of various origins on the distribution of aquatic macrophytes and the pollution gradient of three Mfoundi tributaries.

\section{Materials and methods}

\section{Study area}

The study was carried out in Yaounde, the political capital of Cameroon, situated between $3^{\circ} 30$ and $3^{\circ} 58$ north latitude and $11^{\circ} 20$ and $11^{\circ} 40$ east longitude (Santoir and Bopda, 1995). This city is located on the southern plateau of Cameroon whose average altitude is $760 \mathrm{~m}$ (Abossolo et al., 2015). Yaounde is under the influence of a particular equatorial climate called "Yaounde climate" characterized by average rainfall of $1564.7 \mathrm{~mm} /$ year, an average temperature of $23.5^{\circ}$ $\mathrm{C}$ and the annual thermal amplitude of 2.4 (Abossolo et al., 2015). Four seasons of unequal importance, varying in duration from one year to another, are observed, and are distributed as follows: a long dry season (mid-November to midMarch), a short rainy season (mid-March to midJune), a short dry season (mid-June to midAugust) and a long rainy season (mid-August to mid-November). Only the Northwest and West 
outskirts of Yaounde have few semi-deciduous forest relics with Sterculiaceae and Ulmaceae (Letouzey, 1985). In downtown and the pericentral area, rapid urbanization has decimated the existing forest, the greenery is visible swamp vegetation, fields and public gardens. Its base consists essentially of metamorphic and crystalline formations (Vicat and Bilong 1998 cit. Ebang et al., 2012) that give acidic soils with a $\mathrm{pH}$ below 6 . The hydrographic network consists of Mfoundi and tributaries that irrigate almost the entire city. Mfoundi rises northwest of the city of Yaounde, mountain tops and Febe Mbankolo (1100 m), through the capital and join Mefou by the Borough of Afan-Oyoa. It drains 11 main tributaries: Tongolo, Ntem, Ebogo, Ewoue, Aké, Nkié, Odza (left bank) and Abiergué, Mingoa, Olézoa, Biyemé (right bank). Preliminary work has been done on the 11 tributaries of Mfoundi. The purpose is to list the types of waste and discards observed along the course of the tributary. At the end of this preliminary work, 3 tributaries of Mfoundi were selected (Fig. 1) according to the origins of the effluents they receive:
- The Aké tributary located on the left bank of the Mfoundi watershed where the industries are concentrated (the breweries of Cameroon, the Cameroonian union of breweries, the Coca Cola factory, the SODECAO (cocoa development company) and the SCDP (Cameroonian company of petroleum depots)). Its length is 5.3 $\mathrm{km}$. This tributary receives chemical and organic pollutants of industrial origin;

- The Biyeme tributary located on the right bank of the Mfoundi watershed. Its length $(11.6 \mathrm{~km})$ makes it the most important tributary of the Mfoundi watershed (Foto et al., 2011). This tributary receives chemical and organic pollutants of domestic origin. However, its downstream part located in the Ahala district is considered here as the reference site given its position and its distance from all sources of pollution upstream of this tributary;

- Tributary Ewoué located on the left bank of the catchment basin of Mfoundi. Its length is $3.2 \mathrm{~km}$. It is the only tributary of Mfoundi that is located near a market. Therefore, it receives a chemical and organic pollution of various origins.

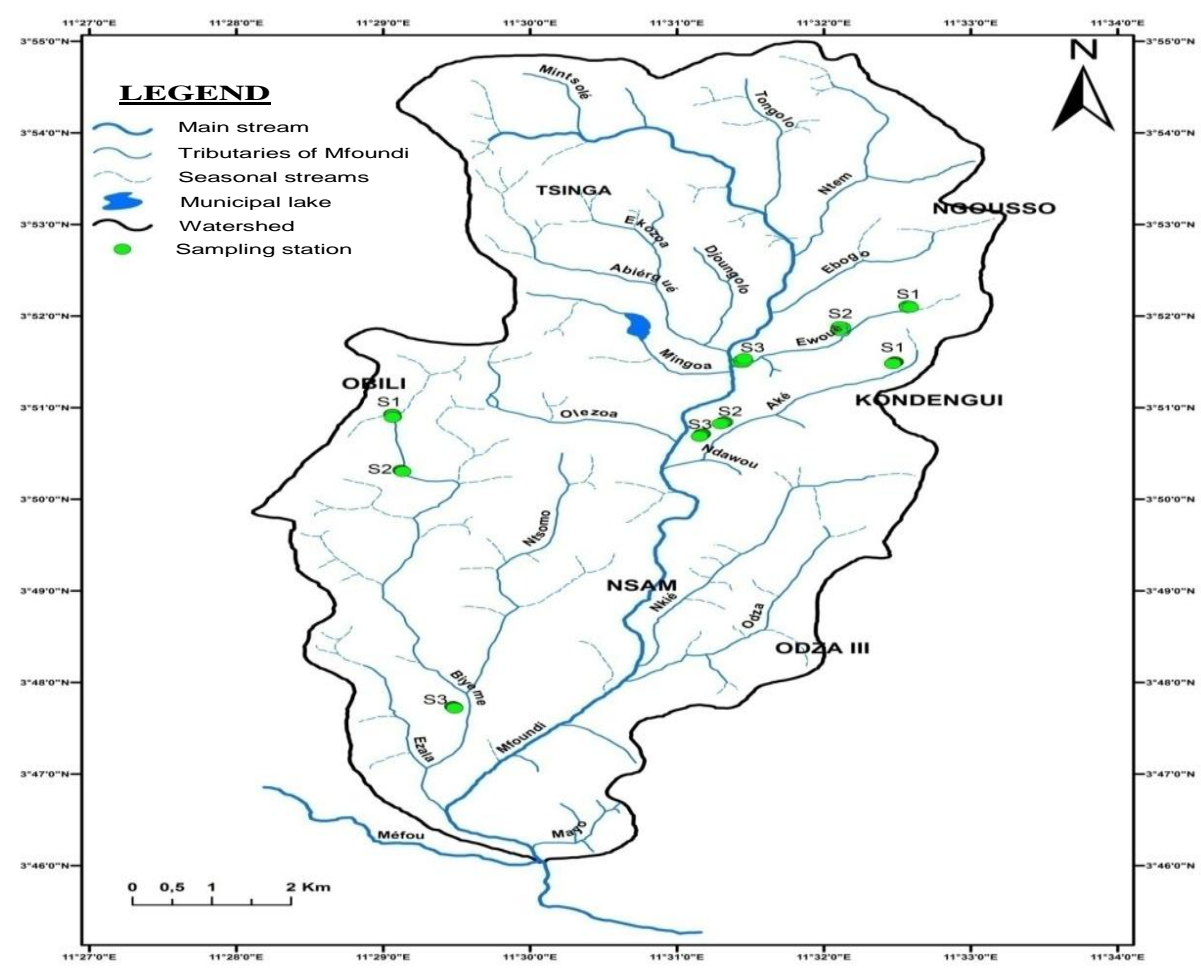

Fig. 1: Location of the 9 sampled stations on the 3 tributaries of the Mfoundi watershed. 


\section{Data collection}

Following the longitudinal gradient of each tributary, 10 plots of $5 \mathrm{~m} \mathrm{x} 5 \mathrm{~m}$ distributed at regular intervals $(5 \mathrm{~m})$ were defined upstream, at an intermediate level and downstream of the tributary before its meeting with Mfoundi. These 3 points (upstream, intermediate and downstream) were considered as sampling stations or sites on each tributary made up a total of 90 plots, or 30 plots per tributary. The floristic survey was carried out during the long dry season and the big rainy season and was based on the identification of all macrophytes present in the sampled plots. Unidentified species in the field were harvested, labeled, pressed and dried; their identification was done by comparison of samples with the specimens of the National Herbarium of Cameroon. According to the average recovery rate of species, each of these species is affected by a Braun-Blanquet abundance-dominance coefficient (Masens, 1997). This coefficient, which varies from + to 5 , is distributed as follows:

$+=$ simple presence, corresponding to an average recovery of 0.5 ;

$1=$ recovery of 1 to $5 \%$, corresponding to an average recovery of 3 ;

$2=$ recovery of 5 to $25 \%$, corresponding to an average coverage of 15 ;

$3=$ recovery of 25 to $50 \%$, corresponding to an average recovery of 37.5 ;

$4=$ recovery of 50 to $75 \%$, corresponding to an average recovery of 62.5 ;

$5=$ recovery greater than $75 \%$, corresponding to an average recovery of 87.5 .

\section{Data analysis}

The floristic data were analyzed using the "Biodiversity R" package, software R version 3.3.3 (Kindt and Coe, 2005). Diversity indices such as Piélou and Shannon were calculated for the floristic characterization of the different stations. In addition to the Sorensen similarity index, the floristic affinities between the different stations were assessed using a Principal Component Analysis.

The average recovery rate (RM) of a species in a given environment, which is the average percentage of occupancy of this specie in each station, was calculated using the dominance coefficient of abundance with the formula: $\mathrm{RMi}=(\mathrm{Ri} /$ total number of records) where $\mathrm{Ri}$ is the total recovery of specie $\mathrm{i}$ in the medium.

The presence index $(\mathrm{Pi})$ corresponds to the average recovery of species $\mathrm{i}$ on the total recovery of individuals. $\mathrm{Pi}=\mathrm{RMi} / \Sigma \mathrm{RM}$.

The Shannon-weaver index $(\mathrm{H}$ ') makes it possible to evaluate the floristic diversity. This index varies according to the average recovery of each species and the number of species present. It is high because a large number of species participate in land occupancy. It is expressed in bits per individual (Frontier et al., 2008; N'da et al., 2008). The formula used is as follows: $\mathrm{H}^{\prime}=-\Sigma \mathrm{pi} \log _{2} \mathrm{pi}$; $\mathrm{Pi}$ is the relative proportion of the average recovery of species $\mathrm{i}$ (values between 0 and 1).

The Piélou equilibrium (J) makes it possible to measure the equidistribution of the species of the stand with respect to an equal theoretical distribution for all the species. It is obtained by the formula: $\mathrm{J}=\mathrm{H}^{\prime} / \log _{2} \mathrm{~S}$; $\mathrm{S}$ is the number of species present. The $\mathbf{J}$ index tends to 0 when there is dominance of a single species and to 1 when a maximum of species participates in the recovery (Frontier et al., 2008; N'da et al., 2008).

The similarity index of Sorensen makes it possible to assess the floristic affinity between two ecological environments. It is greater than 50\% when there is floristic affinity between two environments and less than $50 \%$ otherwise. It is calculated by the following formula: $\mathrm{CS}=(2 \mathrm{c} / \mathrm{a}+$ b) $x 100$ with $(\mathrm{a}=$ number of species of medium $\mathrm{A}$, $\mathrm{b}=$ number of species of medium $\mathrm{B}$ and $\mathrm{c}=$ number of species common to both ecological environments). 


\section{Results}

\section{Specific richness}

A total of 135 species in 102 genera and 44 families were inventoried on the 3 tributaries. The most diverse families in terms of species richness are Asteraceae (16 species), Poaceae (12 species) and Euphorbiaceae (10 species). The most abundant Asteraceae are: Tithonia diversifolia (39.39\%), Struchium sparganophora $(21.81 \%)$ and Acanthospermum hispidum (14.80\%). The most abundant Poaceae are: Pennisetum purpureum (43.56\%), Echinochloa pyramidalis $(24.56 \%)$ and Panicum maximum (12.33\%). The most abundant Euphorbiaceae are: Ricinus communis (49.38\%), Phyllanthus amarus $(21.39 \%)$ and P. acidus (8.23\%).

The Principal Component Analysis represented in Fig. 2 shows 3 plant associations according to the 3 groups observed:

- The first group, positively correlated along the ordinate axis consists solely of the site of Biyeme 3 which is the control site. It moves away completely from all the other stations. The abundant species present only in this site are: Costus afer, Mitragyna stipulosa, Nymphaea lotus, Rhynchospora corymbosa and Setaria megaphylla.

- The second group correlated positively along the abscissa axis consists only of the Aké 2 site. Hydrolea glabra, Leersia hexandra and Pistia stratiotes are 3 abundant and exclusive species at this station which is located at an intermediate level of the Aké tributary. Ipomoea aquatica is another species of this station that is also abundant only in stations that are intermediate to these 3 tributaries (Table 1). These abundant species, which appear abundantly only at the intermediate level of the tributaries, may have an indication of the quality of the water.

- The third group occupying the center of the axes consists of the rest of the other stations. The abundant species of this group are:
Commelina benghalensis, Echinochloa pyramidalis, and Pennisetum purpureum. Fig. 3 shows these species according to their abundance in the whole of the floristic inventory.

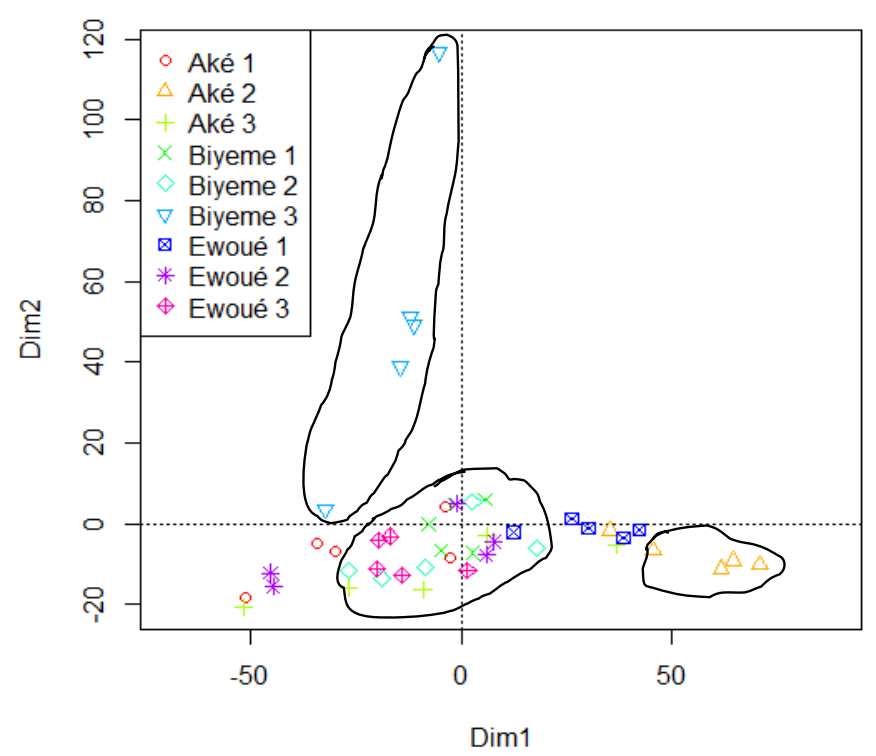

Fig. 2: Principal Component Analysis showing floristic affinities between sites.

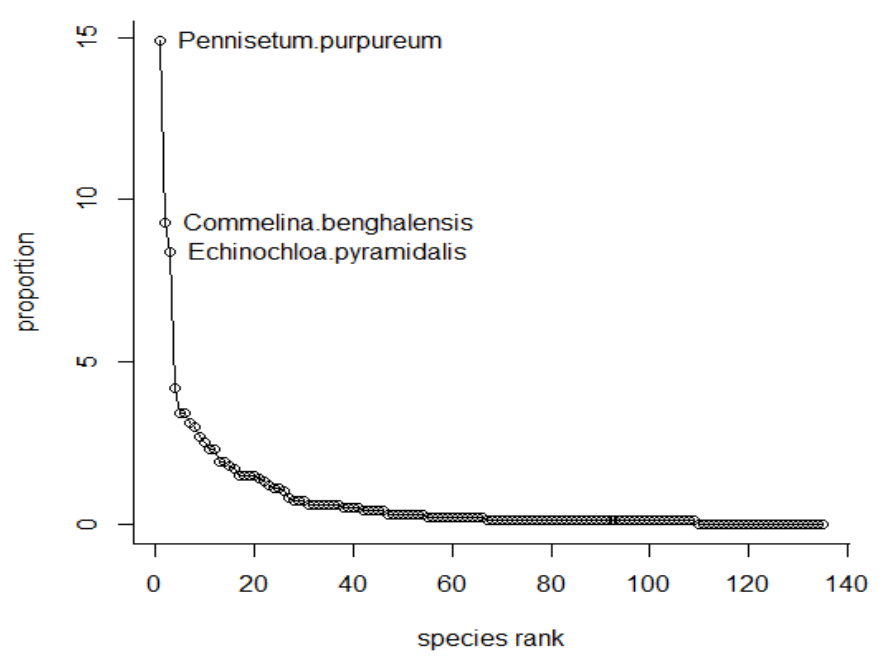

Fig. 3: Curve showing 3 most abundant species in the inventory according to their proportion.

\section{Diversity index}

The species richness decreases from upstream to downstream on the affluent Aké and Ewoué. The 
opposite trend was observed on the Biyeme tributary, where it is stable from upstream to intermediate point and then increases downstream
(Table 2). The Aké 3 station has the smallest number of species ( 28 species) while the Biyeme 3 station has the highest species richness (52 species).

Table 1. Percentage of abundant species in the 3 tributaries.

\begin{tabular}{|c|c|c|c|c|c|c|c|c|c|}
\hline \multirow[b]{2}{*}{ Espèces } & \multicolumn{3}{|l|}{ Aké } & \multicolumn{3}{|c|}{ Biyeme } & \multicolumn{3}{|c|}{ Ewoué } \\
\hline & 1 & 2 & 3 & 1 & 2 & 3 & 1 & 2 & 3 \\
\hline Acroceras zyzanioides & 0.06 & & & & 1.62 & 13.0 & & 1.53 & \\
\hline Alternanthera ficoidea & 1.73 & 0.38 & 7.08 & 5.12 & 4.42 & 0.50 & 6.16 & 4.85 & 1.69 \\
\hline Alternanthera sessilis & 1.73 & 3.88 & 1.77 & 3.56 & 3.98 & 1.17 & 3.56 & 6.94 & 1.64 \\
\hline Amaranthus esculentus & 1.40 & 0.77 & 0.04 & 3.12 & 4.16 & & 0.33 & 0.05 & 1.09 \\
\hline Commelina benghalensis & 8.75 & 7.12 & 5.09 & 12.2 & 8.76 & 7.34 & 14.9 & 12.2 & 9.69 \\
\hline Costus afer & & & & & & 4.17 & & & \\
\hline Echinochloa pyramidalis & 2.81 & 16.7 & 11.5 & 4.05 & 5.70 & 0.33 & 23.5 & 4.85 & 8.59 \\
\hline Hydrolea glabra & & 17.5 & & & & & & & \\
\hline Ipomoea alba & 0.66 & 0.38 & 3.10 & 3.11 & & 0.33 & & & 6.01 \\
\hline Ipomoea aquatica & & 6.35 & & & 11.2 & & 1.47 & 3.93 & \\
\hline Ipomoea batatas & 4.87 & 0.04 & & 4.67 & 4.47 & 5.34 & 7.07 & 1.27 & 4.17 \\
\hline Justicia secunda & 4.21 & & & 8.46 & 0.57 & & 1.41 & & \\
\hline Leersia hexandra & & 5.19 & & & & & & & \\
\hline Ludwigia abyssinica & & 4.62 & 0.66 & 0.04 & 1.14 & 1.37 & & & \\
\hline Luffa aegyptiaca & 3.74 & 0.96 & 2.21 & 1.33 & 5.87 & & & & 3.57 \\
\hline Mitragyna stipulosa & & & & & & 4.00 & & & \\
\hline Nymphaea lotus & & & & & & 4.67 & & & \\
\hline Panicum maximum & 2.07 & 6.15 & 8.42 & 4.00 & 2.63 & 3.50 & 3.68 & 1.84 & 4.57 \\
\hline Pennisetum purpureum & 37.8 & 3.08 & 18.4 & 6.23 & 15.5 & 9.18 & 3.45 & 29.8 & 22.3 \\
\hline Pistia stratiotes & & 3.46 & & & & & & & \\
\hline Polygonum lanigerum & & 3.85 & 1.33 & & & & & 6.89 & 1.49 \\
\hline Polygonum salicifolium & & 3.19 & 2.66 & & & 5.00 & & & \\
\hline Ricinus communis & & & & 1.78 & & & & & 3.98 \\
\hline Rhynchospora corymbosa & & & & & & 7.17 & & & \\
\hline Setaria barbata & 1.80 & 0.96 & & 4.50 & 2.06 & & 0.84 & 1.78 & 0.74 \\
\hline Setaria megaphylla & & & & & & 4.17 & & & \\
\hline Struchium sparganophora & & 1.15 & 2.66 & & & 8.01 & & & \\
\hline Tithonia diversifolia & & & 9.74 & 4.45 & & 0.16 & & 2.96 & 10.5 \\
\hline Xanthosoma mafaffa & 2.14 & 0.11 & 2.66 & 4.67 & 0.78 & & 3.34 & 2.96 & 0.49 \\
\hline Zehneria scabra & 3.94 & & 8.86 & 2.23 & 1.09 & & 1.98 & 3.16 & 3.23 \\
\hline
\end{tabular}

1 = upstream; 2 = intermediate; 3 = downstream.

Table 2. Diversity index in the different study stations.

\begin{tabular}{lclcl}
\hline Tributaries & Stations & Specific richness & Shannon index & Piélou equitability \\
\hline Aké & 1 & 50 & 2.73 & 0.698 \\
& 2 & 45 & 2.92 & 0.766 \\
Biyeme & 3 & 28 & 2.77 & 0.833 \\
& 1 & 46 & 3.32 & 0.866 \\
\multirow{2}{*}{ Ewoué } & 2 & 46 & 3.15 & 0.824 \\
& 3 & 52 & 3.19 & 0.808 \\
& 1 & 50 & 2.92 & 0.745 \\
& 2 & 43 & 2.64 & 0.701 \\
\hline
\end{tabular}


The Shannon diversity index increases from upstream to downstream on the Aké tributary and decreases from upstream to downstream on the Biyeme and Ewoué tributary. The highest Shannon index (3.32) is obtained at Biyeme 1 (Etoug-ebe) and the lowest (2.64) at Ewoué 2 (Corneillet). Table 2 shows that Piélou equitability varies from 0.698 (Aké 1) to 0.866 (Biyeme 1). The similarity coefficients of Sorensen between the control station or Biyeme 3 and the other stations vary from $21.35 \%$ to 39.17 $\%$, so they are all less than $50 \%$ (Table 3 ). These are the lowest similarity indices observed in Table 3.

Table 3. Coefficient of similarity of Sorensen between the different stations.

\begin{tabular}{llllllllll}
\hline & Aké 1 & Aké 2 & Aké 3 & Biyeme 1 & Biyeme 2 & Biyeme 3 & Ewoué 1 & Ewoué 2 & Ewoué 3 \\
\hline Aké 1 & 100 & & & & & & & & \\
Aké 2 & 42.10 & 100 & & & & & & & \\
Aké 3 & 46.15 & 49.31 & 100 & & & & & \\
Biyeme 1 & 62.50 & 46.15 & 59.45 & 100 & & & & \\
Biyeme 2 & 60.41 & 50.54 & 51.35 & 65.21 & 100 & & & \\
Biyeme 3 & 29.41 & 39.17 & 37.5 & 28.57 & 32.65 & 100 & & \\
Ewoué 1 & 55.44 & 45.83 & 40.50 & 59.79 & 61.85 & 21.35 & 100 & & \\
Ewoué 2 & 63.82 & 49.43 & 50 & 60 & 64.44 & 27.08 & 61.05 & 100 & \\
Ewoué 3 & 63.91 & 52.74 & 50.66 & 60.21 & 55.91 & 32.32 & 59.18 & 68.13 & 100 \\
\hline
\end{tabular}

\section{Discussion}

In general, species such as Commelina benghalensis, Echinochloa pyramidalis and Pennisetum purpureum are the most abundant on the entire floristic inventory. Commelina benghalensis was particularly abundant in all sites. This goes in line with the fact that, Commelinaceae have already been recognised in Cameroon as an indicator of pollution of aquatic environments (Priso et al., 2000).

Many studies have also shown that Poaceae are among the most polluting plants (Anoliefo et al., 2008). The different sites studied may be polluted to different types or degrees of pollution since they do not all have the same floristic composition though they all belong to the Mfoundi watershed.

This difference between the sites is observed on the Principal Component Analysis which divides them into 3 groups. The first group formed solely by the control site (Biyeme 3) revealed the species that characterize it. Indeed, the similarity coefficient of Sorensen shows that the control site (Biyeme 3) does not show any marked floristic similarity with all the other stations. The dissimilarity of this flora is characterized by a Sorensen index of less than
$50 \%$. The smaller the Sorensen similarity index, the less similar the sites are (Ngueguim et al., 2010). This can be explained by the fact that the control station located on the Biyeme tributary downstream of the Mfoundi watershed is not close to the houses, though individuals often come to bathe while all the other stations are upstream of this watershed. These stations located upstream of the Mfoundi watershed receive the majority of discharges of urban origin. The second group is formed only by the Aké 2 station which is located near the industries. This site receives industrial and domestic wastewater; effluents from laundries, car garages and wastewater from the cleaning of plastic bottles. Hydrolea glabra, Leersia hexandra and Pistia stratiotes are the abundant and characteristic species of this station. Ipomoea aquatica is an abundant species of this station that also appears only at the intermediate level of the other two tributaries.

Ogbo et al. (2009) report that the high abundance of a species in an altered site may give an indication of the resistance of the plant to this polluting cocktail and provide information on its phyto-remediation potential. Thus, Pistia stratiotes is among the most appropriate plants for phyto-remediation in the tropics (Fonkou et al., 2002) and Ipomoea aquatica 
is often used in combination with other plants (Enydra fluctuans and Commelina nudiflora) in the treatment of wastewater (Nya et al., 2002). Fonkou et al. (2005) identified the presence of heavy metals (cadmium, copper, zinc, lead) in all the compartments of two fish ponds in Yaounde: water, sediments, but also plants (Cyperus papyrus, Enydra fluctuans, Ipomoea aquatica and Echinochloa pyramidalis). These plants have been tested in artificial swamps for sewage treatment. The third group consists of all the other stations. These sites receive domestic wastewater from small businesses and other various human activities including latrines-cannons that contaminate and degrade the quality of water. Commelina benghalensis, Echinochloa pyramidalis and Pennisetum purpureum are the species that thrive in these stations. Moreover, Diop (2010) has shown that interspecific competition can significantly influence the distribution of vegetation because if one species settles first, its growth and proliferation may inhibit the growth of another secondary arrival.

Barendregt and Bio (2003) believe that water, light, temperature and nitrates are the factors that influence macrophytic growth in small streams. The species richness decreases from upstream to downstream on the Aké and Ewoué tributaries. According to Ajeagah et al. (2006), there is a large impact of human activities and intensification of pollution from upstream to downstream of the Mfoundi watershed. All the waters upstream of the Mfoundi watershed cross a swampy area with its phyto-purifying character before arriving at the Biyeme 3 control station. The evolution of the species richness on the Biyeme tributary which is the reverse of that of Aké and Ewoué tributaries corroborate that of Priso et al. (2012) on the Kondi River in Douala as well as that of Dibong and Ndjouondo (2014) on the Kambo River in Douala. In all the stations studied, the Shannon diversity indices are between 2.64 and 3.32; equitability of Piélou is between 0.698 and 0.866 . This means that all the stations are diversified and that a maximum of species participates in the recovery of the surface.

\section{Conclusion}

This study has highlighted pollution indicative plants in a few tributaries of the Mfoundi watershed in the city of Yaounde. Commelina benghalensis, Echinochloa pyramidalis and Pennisetum purpureum are the most abundant species in this polluted watershed. In addition to these species, Hydrolea glabra, Ipomoea aquatica, Leersia hexandra and Pistia stratiotes have characterized the sites receiving industrial pollution (mainly the Aké 2 site on the Aké tributary). On the other hand, the reference site furthest from this urban pollution is characterized by: Costus afer, Mitragyna stipulosa, Nymphaea lotus, Rhynchospora corymbosa and Setaria megaphylla. Abundant species in polluted sites can be tested in artificial swamps for sewage treatment.

\section{Conflict of interest statement}

Authors declare that they have no conflict of interest.

\section{Acknowledgement}

The author thanks his supervisor for the training seminars and those colleagues from the Department of Plant Biology of the University of Yaounde 1 who have devoted their time to the realization of this work.

\section{References}

Abossolo, S.A., Tchindjang, M., Mena, M.S., Batha, R.A.S., 2015. Analyse des précipitations annuelles à la station de Yaoundé de 1895 à 2006. Afrique Science 11(2), 183-194.

Ajeagah, A.G., Njine, T., Foto, S.M., Nola, M., 2006. Assessment of Cryptosporidium ssp. oocysts in some urban water systems in Yaounde (Cameroon) Cameroon J. Exp. Biol. 2(1), 9-15.

Ajeagah, G.A., Foto, S., Njine, T., 2012. Experimentation of immunofluorescence technology in the quantification of Cryptosporidium spp. and Giardia spp. 
(oocysts) in surface water in Yaounde Cameroon. Int. J. Biosci. 2(3), 28-39.

Anoliefo, G.O., Ikhajiagbe, B., Okonokhua, B., Edegbai, B., Obasuyi, D.C., 2008. Metal tolerant species distribution and richness in and around the metal based industries: possible candidates for phytoremediation. Afr. J. Env. Sci. Technol. 2(11), 360-370.

Anonyme, 2013. Etude pilote sur la pollution des eaux de surface et souterraines à Yaoundé et son impact sur la santé des populations riveraines (EPESS). Rapport technique, Institut National de la Statistique, Coopération Allemande, Institut Fédéral des Geosciences et des ressources naturelles (BGR).YaoundéHanovre-Bonn. p. 227

Barendregt, A., Bio, A.M.F., 2003. Relevant variables to predict macrophyte communities in running waters. Ecol. Model. 160 (3), 205-217.

Beyene, A., Addis, T., Kifle, D., Legesse, W., Kloos, H., Triest, L., 2009. Comparative study of diatoms and macroinvertebrates as indicators of severe water pollution: Case study of the Kabena and Akaki rivers in Addis Ababa, Ethiopia. Ecol. Indic. 9, 381-392.

Dibong, S.D., Ndjouondo, G.P., 2014. Inventaire et écologie des macrophytes aquatiques de la rivière Kambo à Douala (Cameroun). J. of Appli. Biosci. 80, 7147-7160.

Diop, N.F., 2010. Intégration de la biodiversité d'eau douce dans le processus de développement en Afrique. Mobilisation de l'information et sites de démonstration. Projet de démonstration du bassin de fleuve Gambie. p. 48.

Djuikom, E., Jugnia, L.B., Nola, M., Foto, S., Sikati, V., 2009. Physicochemical water quality of the Mfoundi River watershed at Yaounde, Cameroon, and its relevance to the distribution of bacterial indicators of faecal contamination. Water Sci. Technol. 60(11), 2841-2849.

Djumyom, W.G.V., Matsodoum, N.P., Letah, N.W.A., Djocgoue, P.F., Kengne, I.M., 2016. Co-composting of sewage sludge and Echinochloa pyramidalis (Lam.) Hitchc. \& Chase plant material from a constructed wetland system treating domestic wastewater in
Cameroon. Afr. J. E. Sci. and Technol. 10(9), 272-282.

Ebang, D.M., Zébazé, S.H.T, Foto, S.M., Kemka, N., Nola, M., Boutin, C., Nguetsop, V.F., Djaouda, M., Njiné, T., 2012. Bioécologie des diatomées épilithiques de la rivière Mfoundi (Yaoundé, Cameroun): diversité, distribution spatiale et influence des pollutions organiques. Revue des sciences de l'eau. J. Water Sci. 25(3), 203-218.

Feudjeu, D.P.I., 2012. Risques sanitaires et environnementaux du rejet des eaux usées au quartier NgoaEkellé à Yaoundé, Yaoundé: Ecole d'infirmiers, des techniciens médicosanitaires et du génie sanitaire.

Fonkou, T., Agendia, P., Kengne, I.M., Amougou, A., Nya, J., 2002. Potentials of water lettuce (Pistia stratiotes) in domestic sewage. Treatment with macrophic lagoon systems in Cameroon. Proceeddings of Inter.Symp. on Env. Pollution Control and Waste Management, Tunis. P. 709-714.

Fonkou, T., Agendia, P., Kengne, I., Amougou, A., Focho, D., Nya, J., Dongmo, F., 2005. Heavy metal concentrations in some biotic and abiotic components of the Olezoa wetland complex (Yaoundé-Cameroun, West Africa). Water Qual. Res. J. Canada. 40(4), 457-461.

Fonkou, T., Fonteh, M.F., Djouss, K.M.B., Amougou, A., 2010. Performances des filtres plantés d'Echinochloa pyramidalis dans l'épuration des eaux usées de distillerie en Afrique subsaharienne. Tropicultura. 28(2), 6976.

Foto, M.S., 1989. Etude de la pollution de deux cours d'eau à Yaoundé: L'Abiergue et le Mfoundi. Etudes physicochimiques et biologiques. Doctorate dissertation, University of Yaounde (Cameroon).

Foto, M.S., Zébazé, T.S.H., Ajeagah, G.A, Nzieleu, T.G.J., Njiné, T., 2011. Ciliates community distribution and Saprobic evaluation of and urban hydrosystem: The Biyeme stream Cameroon (Central Africa). J. Appl. Biosci. 48, 3306-3315.

Frontier, S.D., Pichod-Viale, A. Lepretre, D., Davoult, C., Luczak, 2008. Écosystèmes: 
structure, fonctionnement, évolution, 4e édition, Dunod, Paris. 558p.

Jüttner, I.H., Rothfritz, S.J., Ormerod, 1996. Diatoms as indicators of river quality in the Nepalese Middle Hills with consideration of the effects of habitat-specific sampling. Fresh water Biol. 36, 475-486.

Kemka, N., 2000. Evaluation du degré de trophie du lac municipal de Yaoundé: Etude du milieu, dynamique et structure du peuplement phytoplanctonique. Doctorate dissertation, University of Yaoundé I.

Kindt, R., Coe, R., 2005. Tree diversity analysis. A manual and software for common statistical methods for ecological and biodiversity studies. Nairobi: world Agroforestry Center (ICRAF). p. 207.

Kuitcha, D., Ndjama, J., Tita, A.M., Lienou, G., Kamgang, K.B.V., Ateba, B.H., Ekodeck, G.E., 2010. Bacterial contamination of water points of the upper Mfoundi watershed, Yaounde Cameroon. Afri. J. of Microbiol. Res. 4(7), 568574.

Letouzey, R., 1985. Notice de la carte phytogéographique du Cameroun au 1/50000. Domaine de la forêt dense semi-décidue. IRAYaoundé et ICIV Toulouse. pp.76-85.

Leutche, L.A.R., Fonteh, F.M., Ndam, N. J.R., 2009. La gestion intégrée des ressources en eau (GIRE) au Cameroun: Les préoccupations environnementales affectant la gestion des ressources en eau dans le bassin versant de Mefou. Mémoire de Master, Ingénieur des eaux, forêts et chasses, Département de Foresterie de la Faculté d'Agronomie et des Sciences Agricoles, Université de Dschang. p. 137.

Masens, D.Y.B., 1997. Etude phytosociologique de la région de kikwit (Bandudu, Rép. Dem. du Congo).Thèse Université Libre de Bruxelles. p. 398.

Market, B.A., Breure, A.M., Zechmeister, H.G., 2003. Definitions, strategies, and principles for bioindication (biomonitoring of the environment. In :Market B. A., Breure A. M., Zechmeister H.G. (Eds.), Bioindicators/ biomonitors (principles, assessment, concepts). Elsevier, Amsterdam. pp. 3-38.
N'da, D.H., Adou, Y.C., Nguessan, K.E., Kone, M., Sagne, Y.C., 2008. Analyse de la diversité floristique du parc national de la Marahoué, Centre-Ouest de la Côte d'Ivoire. Afr. Sci. 4 (3), 552-557.

Ngueguim, J.R., Zapfack, L., Youmbi, E., Riera, B., Onana, J., Foahom, B., Makombu, J.G., 2010. Floristic diversity under canopy in forest plantation of Mangombe-Edea (Cameroon). Biotechnol. Agr. Sociol. Env. 14 (1), 167-176.

Niyitetegeka, D., 2001. Bioindicateurs et pathogènes bactériens des eaux du Mingoa et du lac municipal de Yaoundé: Conditions du milieu structures des peuplements, répartition spatiale et fluctuations temporelles. Doctorate dissertation, University of Yaounde I, Cameroon.

Nougang, M.E, Nola, M., Ateba, B.H., Tamatcho, K.B.P., Noah, E.O.V., Moungang, L.M., 2011. Prevalence of pathogenic strains of Escherichia coli in urban streams in the equatorial region of Cameroon (central Africa). J. Appl. Biosci. 48, 3293-3305.

Nya, J., Brissaud, F., Kengne, I.M., Drakides, C., Amougou, A., Atangana, E.R., Fonkou, T., Agendia, P.L., 2002. Traitement des eaux usées domestiques au Cameroun: Performances épuratoires comparées du lagunage à microphytes. Proceedings of International Symposium on Environmental Pollution Control and Waste Management. pp. 726-736.

Ogbo, E.M., Zibigha, M., Odogu, G., 2009. The effect of crude oil on growth of the weed (Paspalum scrobiculatum L.). Phytoremediation potential of the plant. Afr. J. Env. Sci. Technol. 3(9), 229-233.

Priso, R.J., Taffouo, V., Kenne, M., Amougou, A., De Sloover, J.R, 2000. A propos de l'utilisation des Commelinaceae comme indicateurs de la qualité des milieux aquatiques. Sci. Technol. Dev. 7(1), 4-11.

Priso, R.J., Dibong, S.D., Tchinda, M.C., Taffouo, V., Din, N. Amougou, A., 2010. Impacts des eaux polluées sur la croissance, les teneurs en chlorophylles et substances organiques dans les feuilles de deux Poaceae. Int. J. Biol. Chem. Sci. 4(4), 1122-1129. 
Priso, R.J., Oum, G.O., Din, N., 2012. Utilisation des macrophytes comme descripteurs de la qualité des eaux de la rivière kondi dans la ville de Douala (Cameroun-Afrique centrale). J. Appl. Biosci. 53, 3797-3811.

Priso, R.J., Ondo, O.B., Etame, J., Din, N. 2014. Influence de la pollution sur la répartition et le comportement de la végétation dans quelques écosystèmes aquatiques de la région de KribiCameroun. Sciences, Technologies et Développement. 15, 23-32.

Ramade, F., Cosson, R., Echaubard, M., Le Bras, S., Moretau, J.C., Thyraux D.E., 1984. Détection de la pollution des eaux en milieu agricole. Bull. Ecol. 15(1), 21-37

Santoir, C., 1995. La pédologie. Atlas régional Sud Cameroun. Inc. Santoir C. \& Bopda A. (Eds.), Cameroun: ORSTOM et MINREST. p. 53.

Sauberer, N., Zulka, K.P., Abensperg, T.M., Berg, H.M., Bieringer, G., Milasowsky, N., Moser, D., Plutzar, C., Pollheimer, M., Storch, C.,
Trostl, R., Zechmeister, H., Grabherr, G., 2004. Surrogate taxa for biodiversity in agricultural landscapes of Eastern Austria. Biol. Conserv. 117, 181-190.

Soininen, J., 2002. Response of epilithic diatom communities to environmental gradients in some finnish rivers. Int. Rev. Hydrobiol. 87, 1124.

Vasquez, G., Favila, M.E., 1998. Status of the health conditions of subtropica Atezea. Lake, Aquatic Ecosystem Health and Management. pp. 245-255.

Winter, J.G., Duthie, H.C., 1998. Effects of urbanization on water quality, periphyton and invertebrate communities in a Southern Ontario stream. Can. Water Res. J. 23, 235-257.

Zébazé, T.S.H., 2000. Biodiversité et dynamique des populations zooplanctoniques (ciliées, rotifères, cladocères et copépodes du lac municipal de Yaoundé (Cameroun). Doctorate dissertation, University of Yaoundé I, Cameroon.

\section{How to cite this article:}

Tchinda, M.C., Louis, Z., Chimi, D.C., Essono, D.M., Ntsomboh-Ntsefong, G., 2018. Influence of the origin of water pollution on the floristic diversity of macrophytes of the Mfoundi lowlands in the city of Yaounde. Int. J. Curr. Res. Biosci. Plant Biol. 5(8), 29-39.

doi: https://doi.org/10.20546/ijcrbp.2018.508.005 